\title{
Covariance of bacterioplankton composition and environmental variables in a temperate delta system
}

\author{
Ramunas Stepanauskas ${ }^{1,3, *}$, Mary Ann Moran' ${ }^{1}$, Brian A. Bergamaschi ${ }^{2}$, \\ James T. Hollibaugh ${ }^{1}$ \\ ${ }^{1}$ Department of Marine Sciences, University of Georgia, Athens, Georgia 30602-3636, USA \\ ${ }^{2}$ US Geological Survey, California State University, Placer Hall M/S 6129, 6000 J Street, Sacramento, \\ California 95819-6129, USA \\ ${ }^{3}$ Present address: Savannah River Ecology Laboratory, Drawer E, Aiken, South Carolina 29802, USA
}

\begin{abstract}
We examined seasonal and spatial variation in bacterioplankton composition in the Sacramento-San Joaquin River Delta (CA) using terminal restriction fragment length polymorphism (T-RFLP) analysis. Cloned 16S rRNA genes from this system were used for putative identification of taxa dominating the T-RFLP profiles. Both cloning and T-RFLP analysis indicated that Actinobacteria, Verrucomicrobia, Cytophaga-Flavobacterium and Proteobacteria were the most abundant bacterioplankton groups in the Delta. Despite the broad variety of sampled habitats (deep water channels, lakes, marshes, agricultural drains, freshwater and brackish areas), and the spatial and temporal differences in hydrology, temperature and water chemistry among the sampling campaigns, T-RFLP electropherograms from all samples were similar, indicating that the same bacterioplankton phylotypes dominated in the various habitats of the Delta throughout the year. However, principal component analysis (PCA) and partial least-squares regression (PLS) of T-RFLP profiles revealed consistent grouping of samples on a seasonal, but not a spatial, basis. $\beta$-Proteobacteria related to Ralstonia, Actinobacteria related to Microthrix, and $\beta$-Proteobacteria identical to the environmental Clone LD12 had the highest relative abundance in summer/fall T-RFLP profiles and were associated with low river flow, high $\mathrm{pH}$, and a number of optical and chemical characteristics of dissolved organic carbon (DOC) indicative of an increased proportion of phytoplankton-produced organic material as opposed to allochthonous, terrestrially derived organic material. On the other hand, Geobacter-related $\beta$-Proteobacteria showed a relative increase in abundance in T-RFLP analysis during winter/spring, and probably were washed out from watershed soils or sediment. Various phylotypes associated with the same phylogenetic division, based on tentative identification of T-RFLP fragments, exhibited diverse seasonal patterns, suggesting that ecological roles of Delta bacterioplankton were partitioned at the genus or species level.
\end{abstract}

KEY WORDS: Bacterioplankton biogeography $\cdot$ 16S rRNA $\cdot$ T-RFLP $\cdot$ Clone libraries $\cdot$ Dissolved organic matter Resale or republication not permitted without written consent of the publisher

\section{INTRODUCTION}

Microbial metabolism accounts for most of the carbon turnover in aquatic ecosystems, yet our understanding of factors shaping the composition of this critical ecosystem component is still very limited. Several studies indicate that the composition of planktonic bacterial assemblages co-vary with abiotic variables, such as salinity (González \& Moran 1997, Crump et al.
1999, Glöckner et al. 1999, Bouvier \& del Giorgio 2002), aluminum concentration (Methé \& Zehr 1999), and the concentration and character of dissolved organic carbon (DOC) (Methé \& Zehr 1999, Fuchs et al. 2000, Covert \& Moran 2001). In addition, laboratory experiments show that biotic interactions, such as grazing by protists (Simek et al. 2001, Matz et al. 2002) and viral lysis (Wommack \& Colwell 2000), are potentially important in defining the composition of 
bacterioplankton. The effects of individual factors are often difficult to differentiate, however, due to the complexity of ecological interactions and due to the limitations of existing methodology.

Several 16S rRNA fingerprinting techniques based on PCR have been developed for rapid comparison of natural microbial assemblages, including terminal restriction fragment length polymorphism (T-RFLP) analysis (Avaniss-Aghajani et al. 1996). Since PCR amplification of $16 \mathrm{~S}$ rRNA genes gives highly reproducible ratios between amplicons when performed under identical conditions, and due to the analytic precision of TRFLP analysis (Polz \& Cavanaugh 1998, González et al. 2000), multivariate statistical analysis of T-RFLP band intensities has been used successfully to detect shifts in the composition of complex microbial assemblages (Dollhopf et al. 2001). However, PCR-based methods are not suitable to obtain absolute values of phylotype abundances. As an alternative to PCR-dependent methods, fluorescent in situ hybridization (FISH) is used widely for field monitoring of the distribution of bacterioplankton phylogenetic groups. While FISH is not subject to PCR biases (Suzuki \& Giovannoni 1996, Wintzingerode et al. 1997, Polz \& Cavanaugh 1998), this technique typically is applied at kingdom-level phylogenetic resolution, which may be insufficient to examine ecologically relevant patterns in bacterial community composition. In addition, not all cells are identified with FISH probes, and the method fails to detect bacteria with low metabolic activity and low cell wall permeability (e.g. Bouvier \& del Giorgio 2002).

In this study, we examined environmental controls of seasonal and spatial variation of bacterioplankton composition in the Sacramento-San Joaquin River Delta, CA, using T-RFLP analysis and multivariate statistics. Cloned 16S rRNA genes from this system were used to identify taxa dominating T-RFLP profiles. The Delta, located at the eastern end of the northern San Francisco Bay, is particularly interesting for studies of factors controlling bacterioplankton composition because, within a geographically confined area, the Delta encompasses a wide variety of aquatic habitats ranging from deepwater channels to lakes, wetlands and agricultural drains (see Fig. 1, Table 1). The concentration and sources of DOC vary widely, both spatially and seasonally, within the Delta (Jassby \& Cloern 2000). Deep water channels receive most of their DOC from the upper watershed, while wetlands and lakes support substantial production of emergent and floating macrophytes and phytoplankton. Agricultural drains collect water from the organic soils in the Delta and have elevated concentrations of humic-rich DOC. Seasonal variation in hydrology and water chemistry is profound in the Delta, with highest water flow, highest DOC concentration and lowest temperatures occurring from November to April (see Fig. 2).

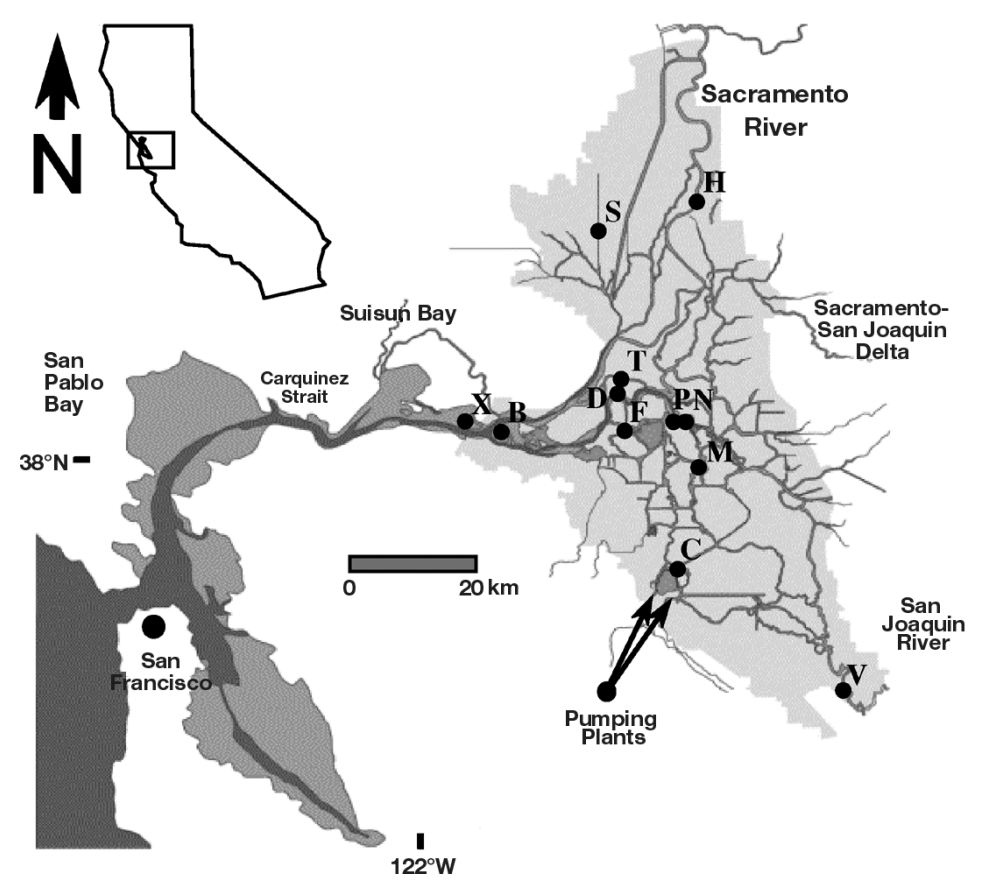

Fig. 1. Sacramento-San Joaquin River Delta, CA, USA, with the location of sampling stations marked. For abbreviations of sampling stations, see Table 1. A photographic presentation of various habitats in the Delta is available at sfbay.wr.usgs.gov/access/wqdata/guide/delta/sitephotos.html

\section{MATERIALS AND METHODS}

Sampling strategy. Twelve sampling stations were selected to represent diverse aquatic habitats in the Delta (Fig. 1, Table 1). Stns $B$ and $X$ were in oligohaline locations and the remaining stations were in freshwater locations. Shallow tidal water habitats (Stns B, F, M, N and S) were sampled during maximum ebb tide to better discriminate material originating from local sources. Deep water in the central Delta (Stn P) was sampled at maximum flood tide. Stn $\mathrm{C}$ was sampled during water intake from the Delta to the Clifton Court forebay, which occurred 1 to $2 \mathrm{~h}$ before the maximum flood tide. The upstream Stns $\mathrm{H}$ and $\mathrm{V}$, the fluctuating salinity front Stn $\mathrm{X}$, the agricultural drain Stn $\mathrm{T}$ and the non-tidal reconstructed wetland Stn D were sampled at various times in the tidal cycle. Water was collected at mid-depth at each station. However, only Stn X had significant vertical stratification, indicated by temperature, dissolved oxygen and conductivity profiles. Four sampling 
Table 1. Sampling stations and times

\begin{tabular}{|c|c|c|c|}
\hline $\begin{array}{l}\text { Abbreviation and } \\
\text { full name }\end{array}$ & Habitat type & Coordinates & Sampling time \\
\hline B - Brown's Island & Natural brackish marsh dominated by Scirpus & $38^{\circ} 02^{\prime} 20^{\prime \prime} \mathrm{N}, 121^{\circ} 52^{\prime} 01^{\prime \prime} \mathrm{W}$ & Max ebb \\
\hline C - Clifton Court & Main inlet to the California State Water Project & $37^{\circ} 49^{\prime} 85^{\prime \prime} \mathrm{N}, 121^{\circ} 33^{\prime} 35^{\prime \prime} \mathrm{W}$ & During water intake \\
\hline D - Demo site & $\begin{array}{l}\text { Marsh reconstructed in } 1997, \\
\text { dominated by Typha and Scirpus }\end{array}$ & $38^{\circ} 06^{\prime} 29^{\prime \prime} \mathrm{N}, 121^{\circ} 38^{\prime} 52^{\prime \prime} \mathrm{W}$ & Varying \\
\hline F - Frank's Tract & Lake created from a flooded island in 1930 s & $38^{\circ} 02^{\prime} 46^{\prime \prime} \mathrm{N}, 121^{\circ} 38^{\prime} 50^{\prime \prime} \mathrm{W}$ & Max ebb \\
\hline H - Hood & Sacramento River upstream of the Delta & $38^{\circ} 22^{\prime} 07^{\prime \prime} \mathrm{N}, 121^{\circ} 31^{\prime} 12^{\prime \prime} \mathrm{W}$ & Varying \\
\hline M - Mildred Island & Lake created from a flooded island in 1983 & $37^{\circ} 59^{\prime} 43^{\prime \prime} \mathrm{N}, 121^{\circ} 30^{\prime} 52^{\prime \prime} \mathrm{W}$ & Max ebb \\
\hline N - Mandeville Tip & Natural freshwater marsh dominated by Scirpus & $38^{\circ} 03^{\prime} 34^{\prime \prime} \mathrm{N}, 121^{\circ} 32^{\prime} 20^{\prime \prime} \mathrm{W}$ & Max ebb \\
\hline P - Prisoner's Point & Deep water channel in the central Delta & $38^{\circ} 03^{\prime} 35^{\prime \prime} \mathrm{N}, 121^{\circ} 33^{\prime} 26^{\prime \prime} \mathrm{W}$ & Max flood \\
\hline S - Shag Slough & Channel of the seasonal Yolo Bypass floodplain & $38^{\circ} 18^{\prime} 22^{\prime \prime} \mathrm{N}, 121^{\circ} 41^{\prime} 32^{\prime \prime} \mathrm{W}$ & Max ebb \\
\hline T - Twitchel Island & $\begin{array}{l}\text { Drain from an agricultural, below-sea-level } \\
\text { island }\end{array}$ & $38^{\circ} 05^{\prime} 48^{\prime \prime} \mathrm{N}, 121^{\circ} 39^{\prime} 01^{\prime \prime} \mathrm{W}$ & Varying \\
\hline V - Vernalis & San Joaquin River upstream of the Delta & $37^{\circ} 40^{\prime} 32^{\prime \prime} \mathrm{N}, 121^{\circ} 15^{\prime} 49^{\prime \prime} \mathrm{W}$ & Varying \\
\hline $\mathrm{X}-\mathrm{X} 2$ & 2-psu front in North San Francisco Bay & Varying & Varying \\
\hline
\end{tabular}

series were performed to cover diverse hydrological and vegetative conditions in the Delta. These occurred during March 19 to 24, July 16 to 21 and October 15 to 20,2000, and February 4 to 9, 2001 (Fig. 2).

DNA collection and extraction. Water samples of 100 to $500 \mathrm{ml}$ were filtered through Sterivex SVG filter cartridges (nominal pore size $0.22 \mu \mathrm{m}$, Millipore) within $12 \mathrm{~h}$ of sample collection. Cartridges were filled with $1.8 \mathrm{ml}$ of lysis buffer $(0.75 \mathrm{M}$ sucrose, $40 \mathrm{mM}$ EDTA, $50 \mathrm{mM}$ Tris [pH 8.3]) and stored frozen until processing. During each sampling series, a blank was prepared by filling an unused Sterivex cartridge with lysis buffer. No PCR product was obtained from any of the blanks.
Due to the high concentration of humic substances in the samples, DNA was extracted using UltraClean Soil DNA Isolation Kit (MoBio). Filters and the liquid phase from Sterivex cartridges were transferred to a $50 \mathrm{ml}$ plastic tube and vortexed at maximal speed for $15 \mathrm{~min}$ together with 1 portion of the bead solution (about $1 \mathrm{ml}), 60 \mu \mathrm{l}$ of $\mathrm{S} 1$ solution and $200 \mu \mathrm{l}$ of IRS solution. $450 \mu \mathrm{l}$ of the resulting slurry was used in further steps of extraction according to the manufacture's instructions. Some extracted DNA samples had to be processed further with Sephadex G-75 spin columns (Moran et al. 1995) to remove remaining humic substances contamination prior to PCR amplification.

Clone library and phylogenetic analysis. Environmental DNA extracted from the Stn M July 2000

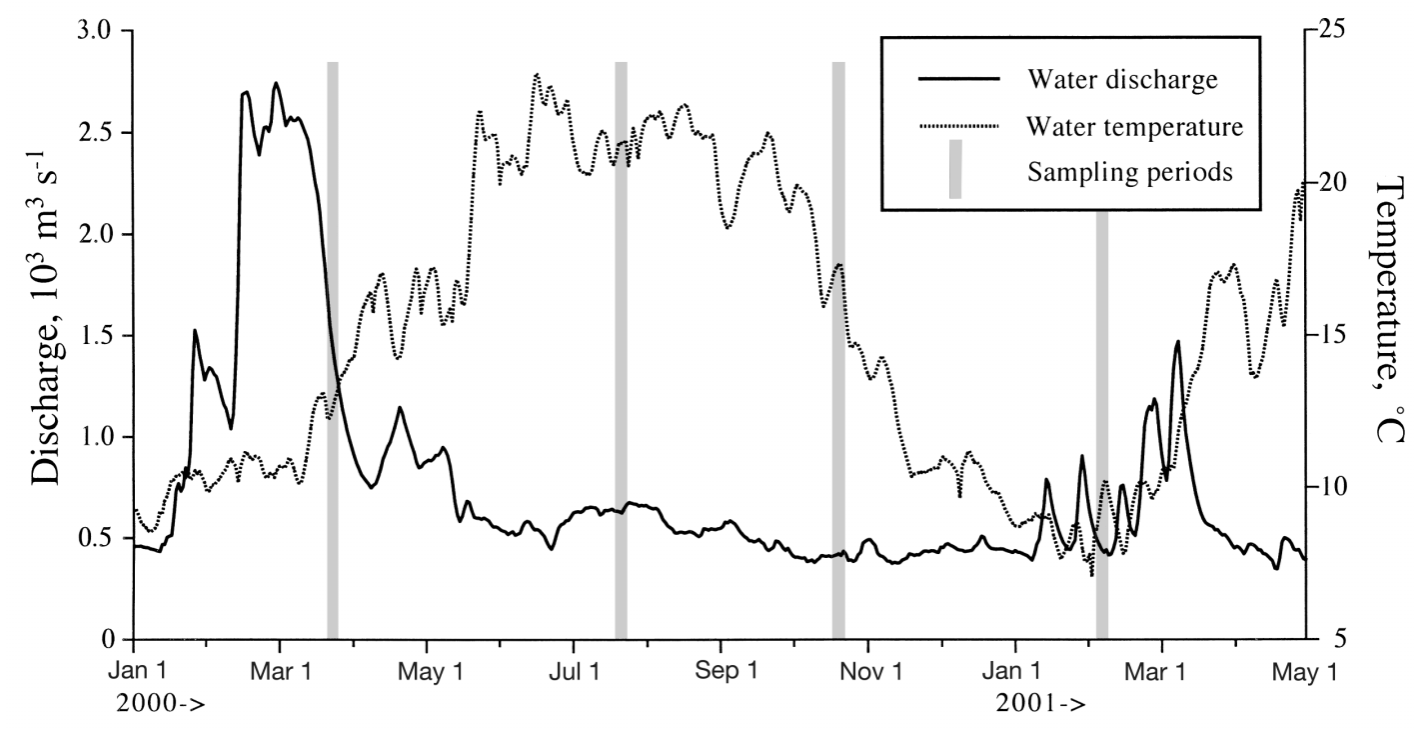

Fig. 2. Combined Sacramento and San Joaquin River flows and Sacramento River water temperature at Stn H (Table 1) during the study period. Data acquired from California Department of Water Resources is available at cdec.water.ca.gov 
sample was used to construct the 16S rRNA gene clone library SFD1. The general bacterial primers 27F (5'AGA GTT TGA TCM TGG CTC AG, where $\mathrm{M}$ is $\mathrm{A}$ or C) and 1518R (5'-AAG GAG GTG ATC CAN CCR CA, where $\mathrm{N}$ is any base, and $\mathrm{R}$ is $\mathrm{A}$ or $\mathrm{G}$ ) were used in PCR amplifications. The $25 \mu \mathrm{l}$ reaction mix contained $50 \mathrm{ng}$ template DNA, $200 \mathrm{nM}$ each primer, 1 U Taq DNA polymerase (Roche), $50 \mu \mathrm{M}$ each deoxynucleoside triphosphate, $2 \mathrm{mM} \mathrm{MgCl}_{2}$ and the buffer $(1 \times$ final conc.). After a hot start at $95^{\circ} \mathrm{C}$ for $3 \mathrm{~min}$, the PCR parameters for 30 cycles were as follows: $45 \mathrm{~s}$ at $95^{\circ} \mathrm{C}, 45 \mathrm{~s}$ at $60^{\circ} \mathrm{C}$ and $3 \mathrm{~min}$ at $72^{\circ} \mathrm{C}$. After the last cycle, the reaction was extended for $10 \mathrm{~min}$ at $72^{\circ} \mathrm{C}$. Negative controls consisted of the PCR reaction mix with $\mathrm{H}_{2} \mathrm{O}$ instead of the DNA extract. PCR products were subjected to electrophoresis in a low-melt agarose gel, and the band of the correct size was removed and extracted with QIAquick gel extaction kit (Qiagen). A clone library was constructed using the TA cloning kit (Invitrogen) with the $\mathrm{pCR} 2.1$ vector according to manufacturer's instructions.

A total of 34 randomly selected clones were sequenced using primers $27 \mathrm{~F}$ and 907R (5'-CCG TCA ATT CCT TTR AGT TT), yielding readable sequences of about $800 \mathrm{bp}$. Sequences were automatically aligned with ClustalX (Thompson et al. 1997) and phylogenetic trees were constructed with the PHYLIP package (Felsenstein 1989) using Jukes-Cantor evolutionary distances and the neighbor-joining method. Phylogenetic affiliations were designated based on the closest sequences retrieved from GenBank using the BLAST search tool (Altschul et al. 1997) and from the Ribosomal Database Project (RDP; Maidak et al. 1994). Five chimeras were detected by constructing alternative phylogenetic trees using $300 \mathrm{bp}$ pieces from $5^{\prime}$ and $3^{\prime}$ ends, and by the CHECK_CHIMERA program of RDP. Chimeras were removed from the data set. Of the 29 non-chimeric sequences, 25 represented 16S rRNA genes of bacteria and 4 sequences appeared to originate from chloroplasts (Table 2). Non-chimeral SFD1 sequences were deposited in GenBank with accession numbers AF491653 to AF491681.

T-RFLP. 16S rRNA genes from environmental samples and SFD1 clones were amplified as above, except that fluorescently labeled forward primers were used. FAM-27F and HEX-27F (Applied Biosystems) were used for environmental samples and clones, respectively. To ensure efficient PCR amplification, $10 \%$ of the forward primer was unlabeled. PCR products were subjected to electrophoresis in a low-melt agarose gel and the band of the correct size was removed and extracted with the Wizard PCR DNA prep purification system (Promega). PCR amplicons (150 ng of environmental samples or $10 \mathrm{ng}$ of clones) were digested for $3 \mathrm{~h}$ with $10 \mathrm{U}$ of $\mathrm{CfoI}$ restriction enzyme $\left(\mathrm{GCG}^{\vee} \mathrm{C}_{\text {; }}\right.$
Roche) in $10 \mu \mathrm{l}$ at $37^{\circ} \mathrm{C}$. The entire volume was precipitated with ethanol and resuspended in $15 \mu \mathrm{l}$ deionized formamide and $0.5 \mu \mathrm{l}$ Genescan 2500 TAMRA size standard (Perkin-Elmer). Before the analysis, samples were denatured for $5 \mathrm{~min}$ at $95^{\circ} \mathrm{C}$ and placed immediately on ice for 3 min. Fragment length was determined on an ABI Prism 310 genetic analyzer in GeneScan mode using $47 \mathrm{~cm} \times 50 \mu \mathrm{m}$ capillaries, POP-4 polymer (Perkin-Elmer), $20 \mathrm{~s}$ injection time, $15 \mathrm{kV}$ injection and run voltage, and $60^{\circ} \mathrm{C}$ capillary temperature. Each clone was co-injected with an environmental sample to ensure identical size calling of matching peaks. Due to a combination of low DNA content and interference from humic substances, some samples could not be amplified and were excluded from further analysis. Excluded were: March 2000 Samples D and $T_{i}$ July 2000 Sample $V_{i}$ October 2000 Samples B, N and T; February 2001 Samples D, M, P, S, T and V.

We used peak height in T-RFLP profiles as a proxy for the relative abundance of taxa represented by restriction fragments in amplicon pools obtained from environmental samples. Integrated peak areas were not used due to overlap of some peaks. Peaks less than 1.5 bases apart from a larger peak were binned. Binned peaks were normalized against the sum of peak heights in a profile. To account for small differences in run time among samples, we considered fragments from different profiles with less than 1 base difference to be the same length. Peaks were assumed to be artifacts and were removed from further analysis if they fulfilled both of the following conditions: (1) They did not contribute more than $1 \%$ to the sum of peak heights in any individual profile; (2) they occurred in less than 3 profiles. A program in Visual Basic for Microsoft Excel was developed to automate this numeric procedure.

Environmental variables. Water-flow data for the Sacramento and San Joaquin rivers were obtained from the State of California Department of Water Resources (Fig. 2). Water temperature, $\mathrm{pH}$ and conductivity were measured in the field. The absorption coefficient at $350 \mathrm{~nm}$ (a350) was calculated as $2.303 \times$ a350/0.01, where a350 is absorbance at $350 \mathrm{~nm}$ and 0.01 is the length of the cuvette in $\mathrm{m}$. The spectral slope coefficient (AbS) was calculated from a partial least-squares linear regression (PLS) of ln-transformed absorbance versus wavelength, in the wavelength range 280 to $400 \mathrm{~nm}$ (Davies-Colley \& Vant 1987). Fluorescence was measured using a SPEX FluoroMax-3 spectrofluorometer with $5 \mathrm{~nm}$ excitation and emission slit widths, controlled with Datamax and Grams/32 software. The ratio of fluorescence at 450 and $500 \mathrm{~nm}$ under excitation at $365 \mathrm{~nm}$ (FluR) was used as an indicator of DOC source, as in McKnight et al. (2001). DOC was measured with a Shimadzu TOC-5000 analyzer. 
Table 2. SFD1 clone library, GenBank BlastN search results. Vertical lines indicate groups of clones with $>97 \%$ sequence similarity. GenBank accession numbers are given in parentheses. T-RFL: terminal restriction fragment length in bp, obtained using $27 \mathrm{~F}$ primer and $\mathrm{CfoI}$ restriction enzyme. Underlined numbers indicate that matching fragments were found in environmental electropherograms. Env.: Environment from which 10 closest relatives in GenBank were found ( $\mathrm{F}=$ freshwater, $\mathrm{M}=\mathrm{marine}, \mathrm{S}=$ soil/ sediment, $\mathrm{D}=$ diverse)

\begin{tabular}{|c|c|c|c|c|}
\hline $\begin{array}{l}\text { SFD1-x clones and } \\
\text { sequence length }\end{array}$ & $\begin{array}{l}\text { T-RFL } \\
\text { (bp) }\end{array}$ & Env. & $\begin{array}{l}\text { Closest sequence and } \\
\text { similarity }\end{array}$ & $\begin{array}{l}\text { Closest identified relative and } \\
\text { similarity }\end{array}$ \\
\hline \multicolumn{5}{|l|}{ Actinobacteria } \\
\hline 1 (AF491653), 798 bp & $\underline{395}$ & $\mathrm{~F}$ & CL500-29 (AF316678), $97 \%$ & Microthrix parvicella (X82546), $88 \%$ \\
\hline 5 (AF491674), $798 \mathrm{bp}$ & $\underline{395}$ & $\mathrm{~F}$ & CL500-29 (AF316678), $97 \%$ & Microthrix parvicella (X82546), $88 \%$ \\
\hline 11 (AF491655), $758 \mathrm{bp}$ & $\underline{395}$ & F & CL500-29 (AF316678), $98 \%$ & Microthrix parvicella (X82546), $88 \%$ \\
\hline 17 (AF491660), $797 \mathrm{bp}$ & $\overline{398}$ & $\mathrm{~F} / \mathrm{S}$ & ARFS-33 (UBA277699), $92 \%$ & Microthrix parvicella (X82546), $91 \%$ \\
\hline 20 (AF491663), $800 \mathrm{bp}$ & $\underline{400}$ & $\mathrm{~F} / \mathrm{S}$ & HT2E3 (AF418967), 96\% & Terrabacter tumescens (AF005023), $93 \%$ \\
\hline 21 (AF491664), $801 \mathrm{bp}$ & $\overline{662}$ & $\mathrm{~F}$ & HT2E3 (AF418967), $98 \%$ & Nostocoida limicola (X85212), 92\% \\
\hline 38 (AF491671), $771 \mathrm{bp}$ & $\underline{662}$ & F & HT2E3 (AF418967), $99 \%$ & Nostocoida limicola (X85212), $91 \%$ \\
\hline 39 (AF491672), 799 bp & $\underline{662}$ & F & GOBB3-CL124 (AF388884), 99\% & Terrabacter tumescens (AF005023), $93 \%$ \\
\hline \multicolumn{5}{|l|}{ Verrucomicrobia } \\
\hline 8 (AF491676), $810 \mathrm{bp}$ & $\underline{202}$ & $\mathrm{~F}$ & CL120-10 (AF316720), $95 \%$ & Fucophilus fucoidanolyticus (AB073978), $93 \%$ \\
\hline $27(\mathrm{AF} 491666), 806 \mathrm{bp}$ & 580 & $\mathrm{~S}$ & Opitutus sp. (X99392), $96 \%$ & Opitutus sp. (X99392), $96 \%$ \\
\hline \multicolumn{5}{|l|}{ Cytophaga-Flavobacterium } \\
\hline 7 (AF491675), 778 bp & $\underline{94}$ & $\mathrm{~F} / \mathrm{M}$ & GOBB3-CL142 (AF388889), 98\% & Flexibacter marinus. (M62788), $91 \%$ \\
\hline 9 (AF491677), 808 bp & $\underline{\overline{94}}$ & $\mathrm{~F} / \mathrm{M}$ & GOBB3-CL142 (AF388889), $97 \%$ & Cyclobacterium marinum (M62788), $91 \%$ \\
\hline 15 (AF491658), 806 bp & $\underline{\overline{94}}$ & $\mathrm{~F} / \mathrm{M}$ & GOBB3-CL142 (AF388889), $97 \%$ & Cyclobacterium marinum (M62788), $91 \%$ \\
\hline 2 (AF491662), $792 \mathrm{bp}$ & $\overline{212}$ & F & Clone 09 (AF361195), 98\% & Flexibacter sp. (AF361187), $90 \%$ \\
\hline 16 (AF491659), $811 \mathrm{bp}$ & $\underline{64}$ & $\mathrm{~S} / \mathrm{F}$ & Clone SC-I-12 (AJ252615), $94 \%$ & Flexibacter sp. (AF361187), $94 \%$ \\
\hline 19 (AF491661), $806 \mathrm{bp}$ & 428 & $\mathrm{D}$ & Clone WCHB1 (AF050545), 85\% & Flavobacterium heparinum (M11657), 84 \% \\
\hline \multicolumn{5}{|l|}{$\alpha$-Proteobacteria } \\
\hline 3 (AF491667), 757 bp & $\underline{518}$ & $\mathrm{~F} / \mathrm{M}$ & LD12 (Z99 & Pedomicrobium australicum (X9 \\
\hline 12 (AF491656), $756 \mathrm{bp}$ & $\underline{518}$ & $\mathrm{~F} / \mathrm{M}$ & LD12 (Z99997), $100 \%$ & Pedomicrobium australicum (X97693), $83 \%$ \\
\hline \multicolumn{5}{|l|}{$\beta$-Proteobacteria } \\
\hline 33 (AF491668, 787 bp & $\underline{145}$ & $\mathrm{D}$ & Ralstonia sp. (AB007998), 92\% & Ralstonia sp. (AB0079 \\
\hline 36 (AF491669), 766 bp & $\underline{542}$ & $\mathrm{~F} / \mathrm{M}$ & LD28 (Z99999), $98 \%$ & Methylophilus leisingerii (AF250333), $95 \%$ \\
\hline 14 (AF491657), $816 \mathrm{bp}$ & $\underline{570}$ & $\mathrm{~F} / \mathrm{M}$ & LD28 (Z99999), $99 \%$ & Methylophilus methylotrophus (L15475), $91 \%$ \\
\hline 25 (AF491665), $824 \mathrm{bp}$ & $\underline{570}$ & $\mathrm{~F} / \mathrm{M}$ & LD28 (Z99999), $99 \%$ & Methylophilus methylotrophus (L15475), $91 \%$ \\
\hline \multicolumn{5}{|l|}{$\delta$-Proteobacteria } \\
\hline 10 (AF491654), 804 bp & $\underline{80}$ & $\mathrm{~S}$ & TIHP368-19 (AB031638), $84 \%$ & Geobacter grbicium (AF335183), 81\% \\
\hline 40 (AF491673), $818 \mathrm{bp}$ & $\underline{80}$ & $\mathrm{~S}$ & TIHP368-19 (AB031638), $84 \%$ & Geobacter grbicium (AF335183), 81 \% \\
\hline \multicolumn{5}{|l|}{ Fibrobacter } \\
\hline 37 (AF491670), $778 \mathrm{bp}$ & 348 & $\mathrm{~S}$ & $\begin{array}{l}\text { Gemmimonas aurantiaca } \\
\text { (AB072735), } 90 \%\end{array}$ & Gemmimonas aurantiaca (AB072735), $90 \%$ \\
\hline \multicolumn{5}{|l|}{ Chloroplasts } \\
\hline 22 (AF491679), $581 \mathrm{bp}$ & $\underline{376}$ & $\mathrm{~F} / \mathrm{M}$ & $\begin{array}{l}\text { Skeletonema pseudocostatum } \\
\text { (X82155), } 96 \%\end{array}$ & Skeletonema pseudocostatum (X82155), $96 \%$ \\
\hline 13 (AF491678), $509 \mathrm{bp}$ & - & $\mathrm{F} / \mathrm{M}$ & OCS20 (AF001654), 98\% & Pyrenomonas salina (X55015), $95 \%$ \\
\hline 26 (AF491680), $497 \mathrm{bp}$ & - & $\mathrm{D}$ & OCS182 (AF001660), $95 \%$ & Mantionella squamata (X90641), 93\% \\
\hline 34 (AF491681), $506 \mathrm{bp}$ & - & $\mathrm{D}$ & OCS182 (AF001660), $95 \%$ & Mantionella squamata (X90641), 93\% \\
\hline
\end{tabular}

DOC fractionation into humic, fulvic and hydrophilic components was achieved by sequential extraction on non-ionic macroporous resins XAD-8 and XAD-4 (Malcolm \& MacCarthy 1992). DOC bioavailability was determined as oxygen consumption by the natural microbial assemblage during $14 \mathrm{~d}$ in nutrient-sufficient cultures at $15^{\circ} \mathrm{C}$ in the dark, as in Covert \& Moran (2001). Bacterial abundance was measured using SYTO-13 nucleic acid stain (Molecular Probes) with FACSSort and FACSCalibur (Becton Dickinson) flow cytometers, as in del Giorgio et al. (1996).
Multivariate statistics. Principal component analysis (PCA) and partial least squares regressions (PLS) were performed using The Unscrambler 6.11 software (Camo). These statistical techniques are not sensitive to covariance and uneven variance among the variables and do not require the analytical error in predictor variables to be negligible. Before the analysis, all variables were autoscaled: the geometric means were centered to 0 and all data were normalized for SD. Full cross validation was used in the modeling procedure with 1 sample excluded at a time. $\mathrm{Q}^{2}$ is the coefficient 
of determination for a regression, i.e. the proportion of variance in the response variable being explained by the model.

\section{RESULTS}

The SFD1 clone library contained 25 bacterial sequences, of which 8 were identified as Actinobacteria, 6 as Cytophaga-Flavobacterium (CF), 4 as $\beta$-Proteobacteria, 2 each as Verrucomicrobia, $\alpha$-Proteobacteria and $\delta$-Proteobacteria, and 1 as Fibrobacter (Table 2). Assuming that clones with $>97 \%$ similarity represent the same species, CFD1 clone library covered $56 \%$ of the total diversity in PCR amplicons of the sample, calculated as $[1-(\mathrm{n} / \mathrm{N})] \times 100$, where $\mathrm{n}(=11)$ is the number of unique sequences and $\mathrm{N}(=25)$ is the total number of bacterial sequences (Table 2; Good 1953).

The $2 \alpha$-Proteobacteria (SFD1-3 and SFD1-12) were identical to the LD12 clone (over the 757 bp sequence overlap) retrieved from eutrophic Lake Loosdrecht in The Netherlands, to the CR-FL10 clone from the Columbia River in the western USA (410 bp overlap), and to the SY1-49 clone from Lake Soyang in South Korea (392 bp overlap; GenBank BlastN search; Table 2). SFD1-3 and SFD1-12 also were $>99 \%$ similar to Clones HTH6 and CL120-34, retrieved from the Horsetooth Reservoir in Colorado and from the ultraoligotrophic Crater Lake in Oregon, USA, respectively. Sequences with $>99 \%$ similarities were also found for $\beta$-Proteobacteria SFD1-14 and SFD1-25 (Clone LD28 from Lake Loosdrecht, Clone ACK-C30 from the acidic lake Carry Pond in New York State, USA, and Clone CRE-FL73 from the Columbia River) and for Actinobacteria SFD1-38 (Clone HT2E3 from the Horsetooth Reservoir) and SFD1-39 (Clone GOBB3-CL124 from the River Öre in northern Sweden).

T-RFLP analysis of bacterial clones using 27F primer and $C f o I$ restriction enzyme gave terminal restriction fragments in the size range from 64 to $662 \mathrm{bp}$ (Table 2). In no case did 2 clones with $<97 \%$ sequence similarity have identical fragment lengths, except for Actinomycete SFD1-39, which had an identical fragment length with Actinobacteria SFD1-21 and -38, but was only $92 \%$ similar to the latter 2 clones. In turn, all clones with $>97 \%$ sequence similarity had identical terminal restriction fragments. This provided for a robust putative identification of T-RFLP peaks in environmental samples, based on matches with the clone library. Fiftyfive unique peaks could be distinguished in environmental T-RFLP profiles, out of which 13 peaks matched expected fragment lengths of SFD1 clones.

Sampling periods of the study represented diverse hydrologic and climatic conditions in the Delta (Fig. 2). March 2000 samples were collected at the end of a large winter flood with temperatures starting to rise after the winter minimum. July and October 2000 samples represented mid- and late summer conditions with low river water flow and temperatures at their annual maximum (July) or in the beginning of a decline (October). February 2001 samples were collected between several small winter floods with water temperature at its annual minimum. Average water conductivity in the sampled water was lowest (741 milisiemens $[\mathrm{mS}] \mathrm{cm}^{-1}$ ) during the March sampling and highest $(1117 \mathrm{mS}$ $\mathrm{cm}^{-1}$ ) during the October sampling, while average $\mathrm{pH}$ was lowest (7.2) in March and highest (7.7) in July (Table 3). Average concentrations of dissolved oxygen and DOC, and the absorption coefficient (a350) were highest during February samplings: $11.1 \mathrm{mg} \mathrm{l}^{-1}, 747$ $\mu \mathrm{M}$ and 20.7, respectively. March samples had the

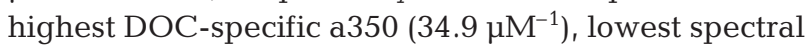
slope coefficient (AbS; 0.0133), lowest fluorescence ratio (FluR; 1.43), lowest DOC bioavailability $(5.4 \%)$ and lowest bacterial abundance $\left(6.5 \times 10^{9} \mathrm{l}^{-1}\right)$. The fraction of DOC in humic, fulvic and hydrophilic acids did not show clear seasonal differences.

Among the sampling stations, average temperature was somewhat higher in the open water stations of the Delta (Stns C, F, M, P, V and X; 15.1 to $16.8^{\circ} \mathrm{C}$ ), as compared to the Sacramento River upstream of the Delta (Stn $\mathrm{H} ; 14.4^{\circ} \mathrm{C}$ ), marshes (Stns $\mathrm{B}, \mathrm{D}, \mathrm{N}$ and $\mathrm{S} ; 13.0$ to $\left.14.8^{\circ} \mathrm{C}\right)$, and the agricultural drain $\operatorname{Stn} \mathrm{T}\left(11.9^{\circ} \mathrm{C}\right)$ (Table 3). Average conductivity was highest at the brackish Stns B $\left(2743 \mathrm{mS} \mathrm{cm}^{-1}\right)$ and X (3986 $\left.\mathrm{mS} \mathrm{cm}^{-1}\right)$. In the freshwater stations, average conductivity varied by a factor of 5 , with the highest and the lowest values occurring at Stns $\mathrm{T}\left(698 \mathrm{mS} \mathrm{cm}^{-1}\right)$ and $\mathrm{H}\left(145 \mathrm{mS} \mathrm{cm}^{-1}\right)$, respectively. Average $\mathrm{pH}$ was highest at $\mathrm{Stn} \mathrm{F}$ (8.1) and lowest at Stn $\mathrm{T}(7.0)$. The highest and the lowest average dissolved oxygen concentrations were observed at Stns $\mathrm{F}\left(12.7 \mathrm{mg} \mathrm{l}^{-1}\right)$ and $\mathrm{T}\left(4.1 \mathrm{mg} \mathrm{l}^{-1}\right)$, respectively. Stn $\mathrm{H}$ had the lowest average DOC concentration $(159 \mu \mathrm{M})$, bioavailable DOC concentration $(19.9 \mu \mathrm{M})$ and a350 (4.2), while Stn T had the highest values of the 3 variables: $1376 \mu \mathrm{M}, 84.3 \mu \mathrm{M}$ and 50.7 , respectively. Stns T and V had the highest $\left(37.2 \mu \mathrm{M}^{-1}\right)$ and the lowest $\left(19.1 \mu^{-1}\right)$ a350/DOC, respectively. The highest and the lowest average values of AbS were found at Stns V (0.0157) and F (0.0140), while highest and lowest average values of FluR were found at Stns H (1.69) and $\mathrm{T}$ (1.46). Stn $\mathrm{T}$ had the highest average proportion of DOC in the form of humic acids $(53.6 \%)$ and the lowest average proportion of DOC in fulvic acids $(23.7 \%)$. In turn, the lowest fraction of humic DOC (43.5 and $44.1 \%$ ) and the highest fraction of fulvic DOC (35.5 and $36.2 \%$ ) were found at Stns V and X. The proportion of hydrophilic DOC averaged 20 to $23 \%$ at all stations. Stns $\mathrm{H}$ and $\mathrm{M}$ had the highest average DOC bioavailability (12\%), while Stn T had 
the lowest average DOC bioavailability $(7 \%)$. Bacterial abundance was highest at Stns $\mathrm{T}\left(9.1 \times 10^{9} \mathrm{l}^{-1}\right)$ and $\mathrm{M}\left(9.0 \times 10^{9} \mathrm{l}^{-1}\right)$, and lowest at Stn X $\left(3.5 \times 10^{9} \mathrm{l}^{-1}\right)$.

Differences among the environmental T-RFLP profiles were relatively small, with the same dominant fragments occurring in most of the profiles (Figs. $3 \& 4$ ). Fragments that averaged more than $3 \%$ to the sum of peak heights in profiles included

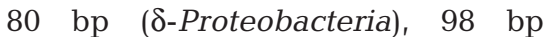
(unidentified), 202 bp (Verrucomicrobia), 204 bp (unidentified), 518 bp ( $\beta$-Proteobacteria), 565 bp (unidentified), $570 \mathrm{bp}$ ( $\beta$-Proteobacteria) and 662 bp (Actinobacteria) peaks. Most of the dominant peaks, corresponding to $65 \%$ (median) of the total T-RFLP peak height, could be putatively identified by matching clones (Fig. 4). Median contributions by the various phylogenetic groups were as follows: Verrucomicrobia (24\%; 202 bp peak), Actinobacteria $(21 \% ; 395,398,400$ and $662 \mathrm{bp}$ peaks), $\delta$-Proteobacteria $(7 \% ; 80 \mathrm{bp}$ peak), $\beta$-Proteobacteria (4\%; 145, 542 and 570 bp peaks), CytophagaFlavobacterium $(3 \% ; 64$ and $94 \mathrm{bp}$ peaks) and $\alpha$-Proteobacteria $(2 \%$, 518 bp peak).

To discriminate general patterns of phylotype distribution among the environmental samples, PCA was performed using normalized heights of terminal restriction fragment peaks as input variables. The first 2 principal components, PC1 and PC2, explained 11 and $9 \%$, respectively, of the total variation in the peak height (Fig. 5). PCA revealed clear seasonal separation along PC1, with winter/spring samples grouping on the negative side and summer/fall samples on the positive side (Fig. $5 \mathrm{~A})$. At the 2 extremes of the PC1 axis were Stn $\mathrm{S}$ samples from March 2000 (negative loading) and October 2000 (positive loading). Among the identified peaks, the $80 \mathrm{bp}$ fragment ( $\delta$-Proteobacteria) had the most negative PC1 loading, while the $395 \mathrm{bp}$ (Actinobacteria), 145 bp, ( $\beta$-Proteo-

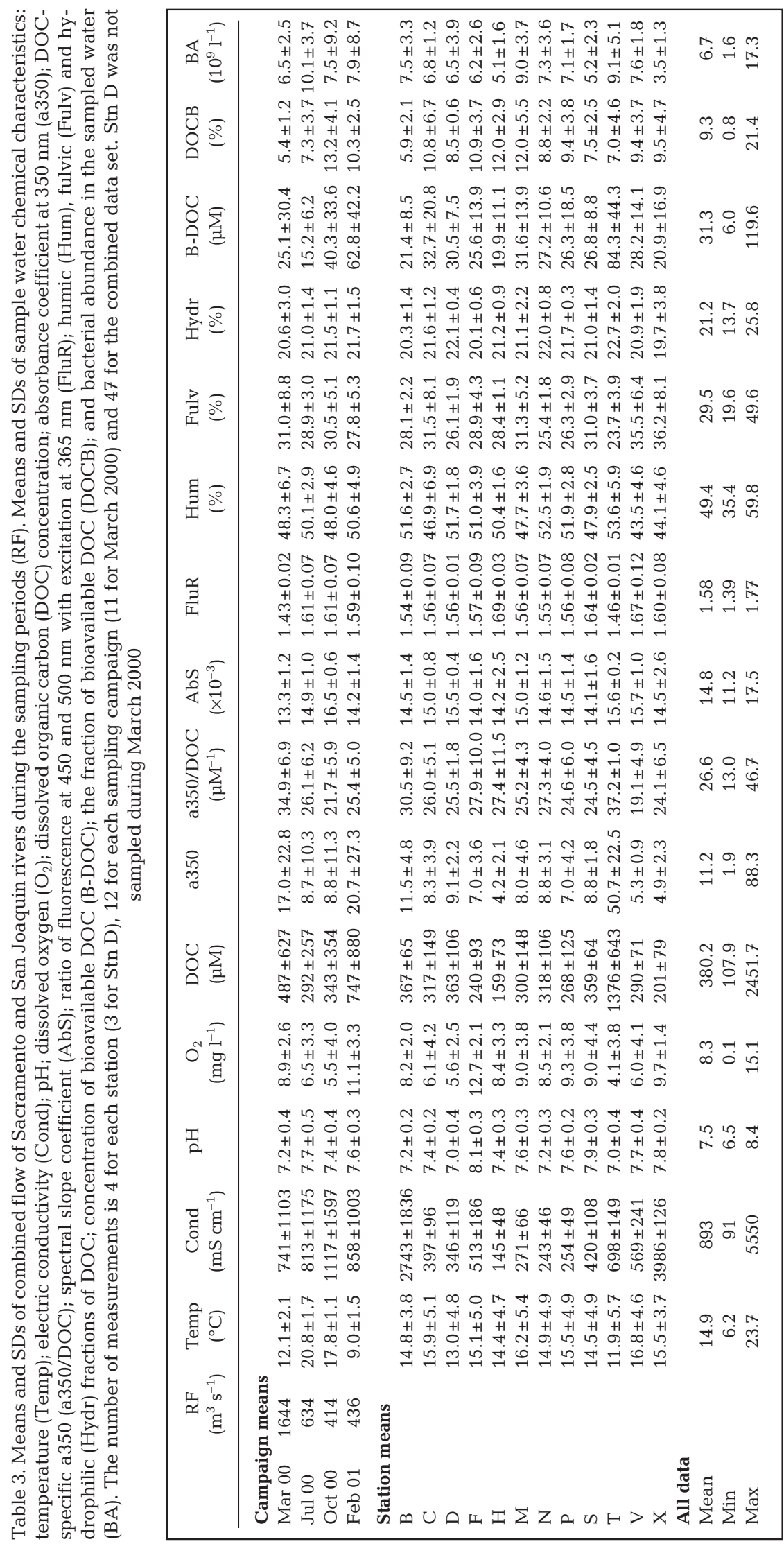




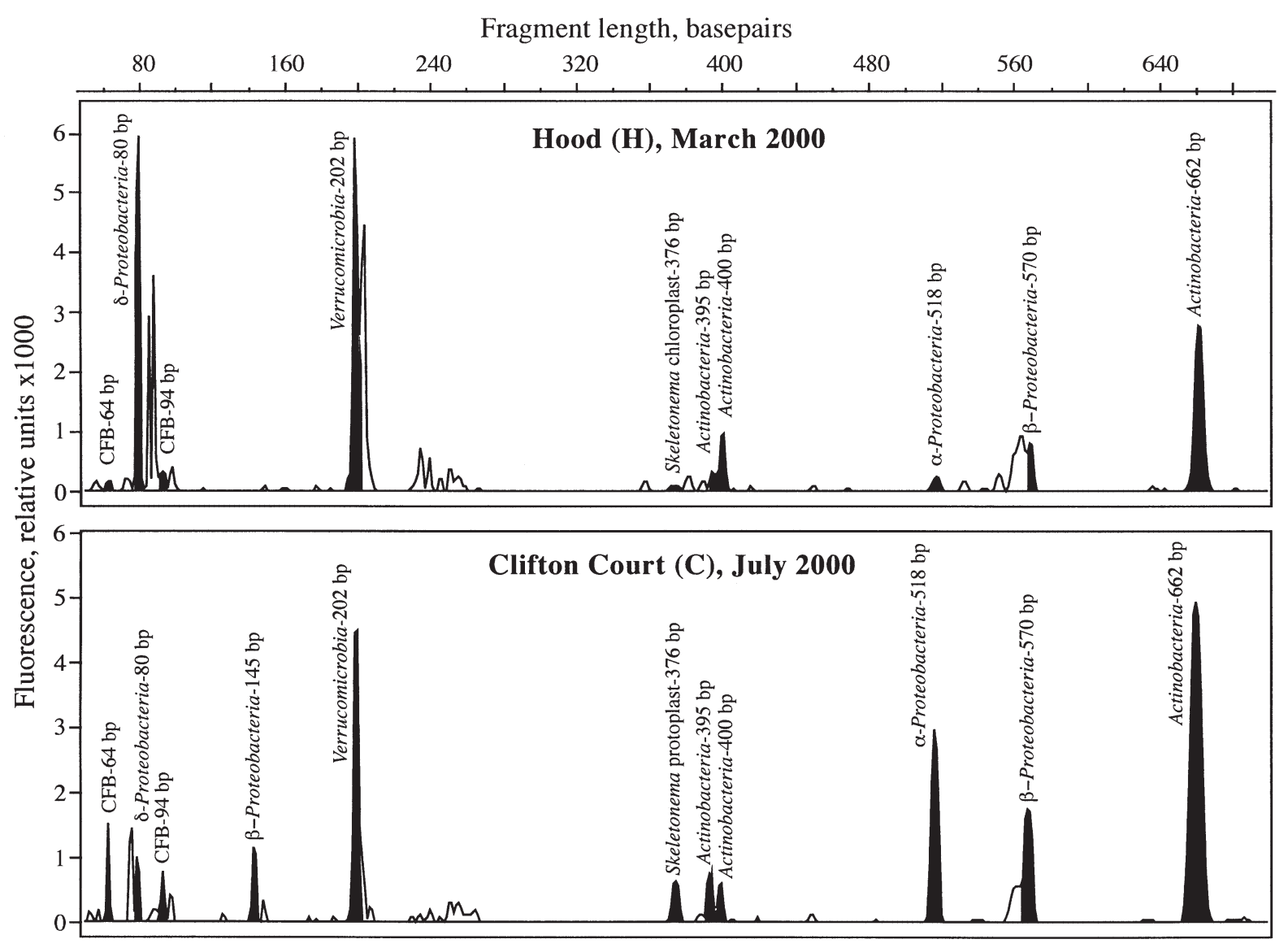

Fig. 3. Examples of environmental T-RFLP profiles. (Upper panel) March 2000 Stn H, (lower panel) July 2000 Stn C. Filled peaks indicate that matching clones were obtained for tentative peak identification

bacteria), 518 bp ( $\alpha$-Proteobacteria) and 376 bp (Skeletonema chloroplast) fragments had the most positive PC1 loadings (Fig. 5B).

No consistent spatial distribution patterns were evident from the PCA analysis (Fig. 5A). Individual habitat types, such as lakes (Stns F and M) and marshes (Stns B, N and D) did not group together in the PC1 and PC2 scattergrams of sample scores. Brackish water Stns B and X did not separate from the freshwater stations. Furthermore, there was no consistent grouping of samples taken from the same station during winter/spring samplings (March 2000 and February 2001) or the summer/fall samplings (July and October 2001).

We employed PLS to determine how variance in the intensity of the identified T-RFLP peaks and bacterial cell abundance (Y variables) is associated with the available environmental data (X variables). The first 2 latent variables (LV1 and LV2) of the model explained $8 \%$ each of the total variation in the $\mathrm{Y}$ variables (Fig. 6). As with the PCA performed on the entire T-RFLP data set, PLS showed a clear separation of samples into winter/spring (March 2000 and February
2001) and summer/fall (July and October, 2000) groups along the LV1 axis (Fig. 6A). Both winter/spring and summer/fall sample groups were divided into 2 subgroups along the LV2 axis. However, the latter pattern could not be attributed to any obvious grouping by sampling time or habitat type. Among X variables, LV1 was influenced negatively by river flow, DOC concentration, a350, a350/DOC and the proportion of humic DOC, while it was influenced positively by $\mathrm{pH}$, temperature, AbS, FluR, the proportion of fulvic DOC and DOC bioavailability (Fig. 6B). The LV2 was influenced mostly by the concentration of bioavailable DOC, conductivity and dissolved oxygen (all positively), and by temperature (negatively). Most of the identified T-RFLP peaks were situated on the positive side of LV1 (representing summer/fall samples), with the highest loadings by $518 \mathrm{bp}(\alpha$-Proteobacteria), $145 \mathrm{bp}$ ( $\beta$-Proteobacteria), $395 \mathrm{bp}$ (Actinobacteria) and $570 \mathrm{bp}(\beta-$ Proteobacteria) fragments. In contrast, 80 bp $(\delta$-Proteobacteria), 398 and 400 bp (Actinobacteria), and 64 bp (CF) fragments as well as bacterial abundance had negative LV1 loadings (representing winter/spring 
samples). The 542 bp ( $\beta$-Proteobacteria) fragment had the highest positive LV2 loading. The highest predictability was achieved for the $518 \mathrm{bp}$ ( $\alpha$-Proteobacteriav), 145 bp ( $\beta$-Proteobacteria) and $395 \mathrm{bp}$ (Actinobacteria) fragments with corresponding $\mathrm{Q}^{2}$ values of 0.61 , 0.61 and 0.55 .

\section{DISCUSSION}

\section{Bacterioplankton composition}

Actinobacteria were abundant in the Sacramento-San Joaquin Delta, as indicated by their dominance in the SFD1 clone library (Table 2, Fig. 7) and in T-RFLP profiles (Figs. $3 \& 4$ ). The high abundance of Actinobacteria might be a general feature in fresh waters since they make up as much as $23 \%$ of all published freshwater bacterioplankton clone sequences produced with general bacterial 16S rRNA primers (Fig. 7). While $\beta$-Proteobacteria can dominate freshwater clone

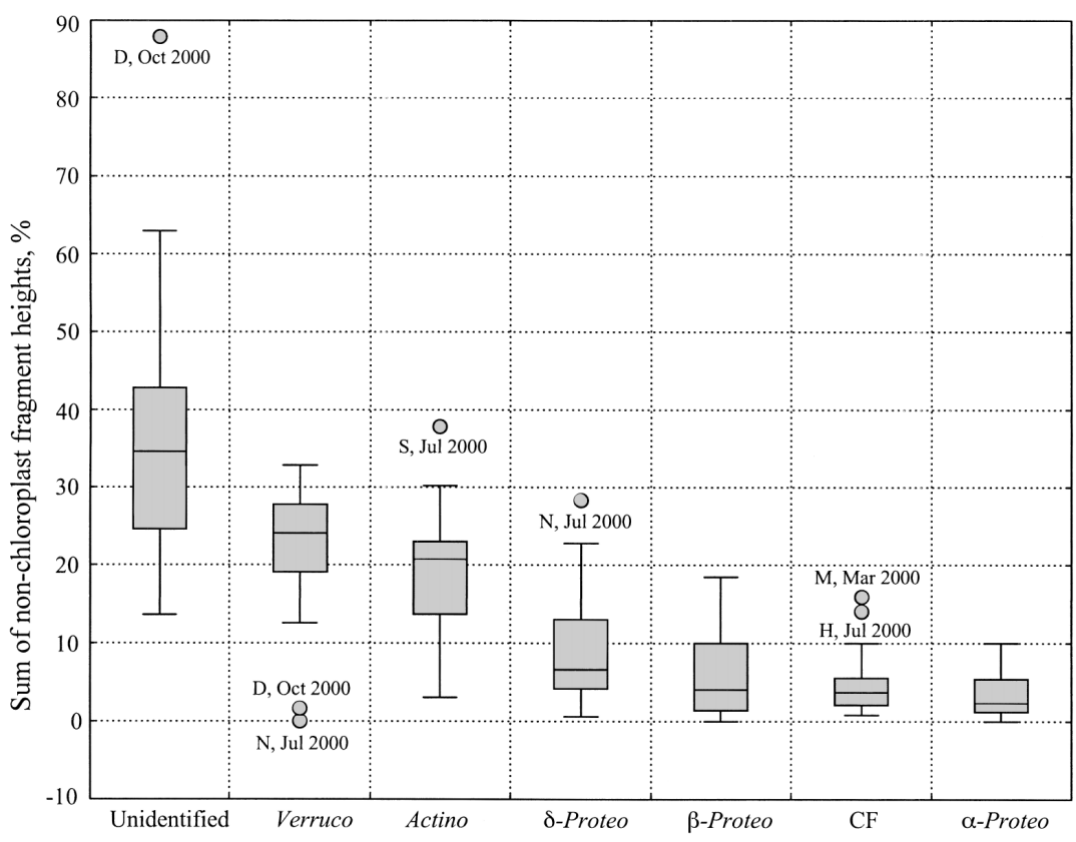

Fig. 4. Contribution of different bacterial phylogenetic groups to the sum of normalized peak heights in environmental T-RFLP profiles from the Sacramento-San Joaquin River Delta. Fragments were tentatively identified by matching clones (Table 2). Median, $25 \%$ percentiles, range and outliers are shown. $\mathrm{N}=35$. For sample abbreviations, see Table 1

libraries (Bahr et al. 1996, Hiorns et al. 1997, Semenova \& Kuznedelov 1998, Crump et al. 1999, Glöckner et al. 2000), there are many exceptions. Actinobacteria have been found to be the most numerous phylogenetic group in clone libraries from the oligotrophic Lake Baikal (Glöckner et al. 2000) and Crater Lake (Urbach et al. 2001), and

from the organic matter-rich Sacramento-San Joaquin River Delta (this study), while the CF cluster has dominated libraries from the oligotrophic Lake Gossenköllesee (Glöckner et al. 2000) and the eutrophic Lake Loosdrecht (Zwart et al. 1998). Based

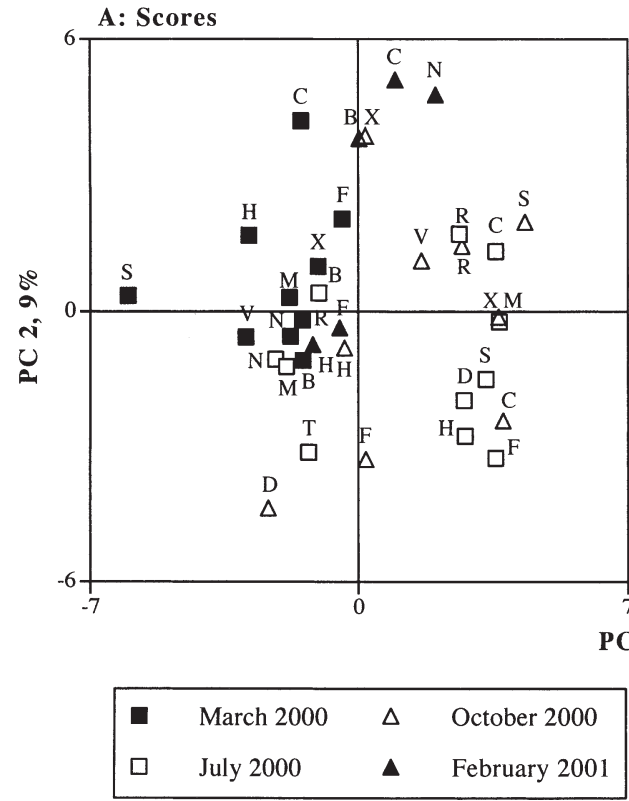

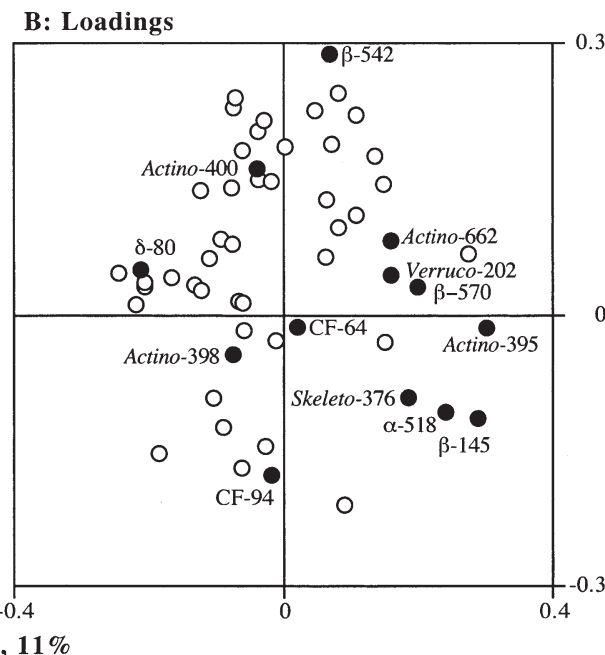

Identified peaks $\bigcirc$ Unidentified peaks
Fig. 5. First 2 principal components (PC) from a principal component analysis (PCA) of environmental T-RFLP profiles, where normalized intensities of T-RFLP peaks were used as input variables. (A) Scores of individual samples, (B) loadings of terminal restriction fragments. Fragments were tentatively identified by matching clones (Table 2). For sample abbreviations, see Table 1 

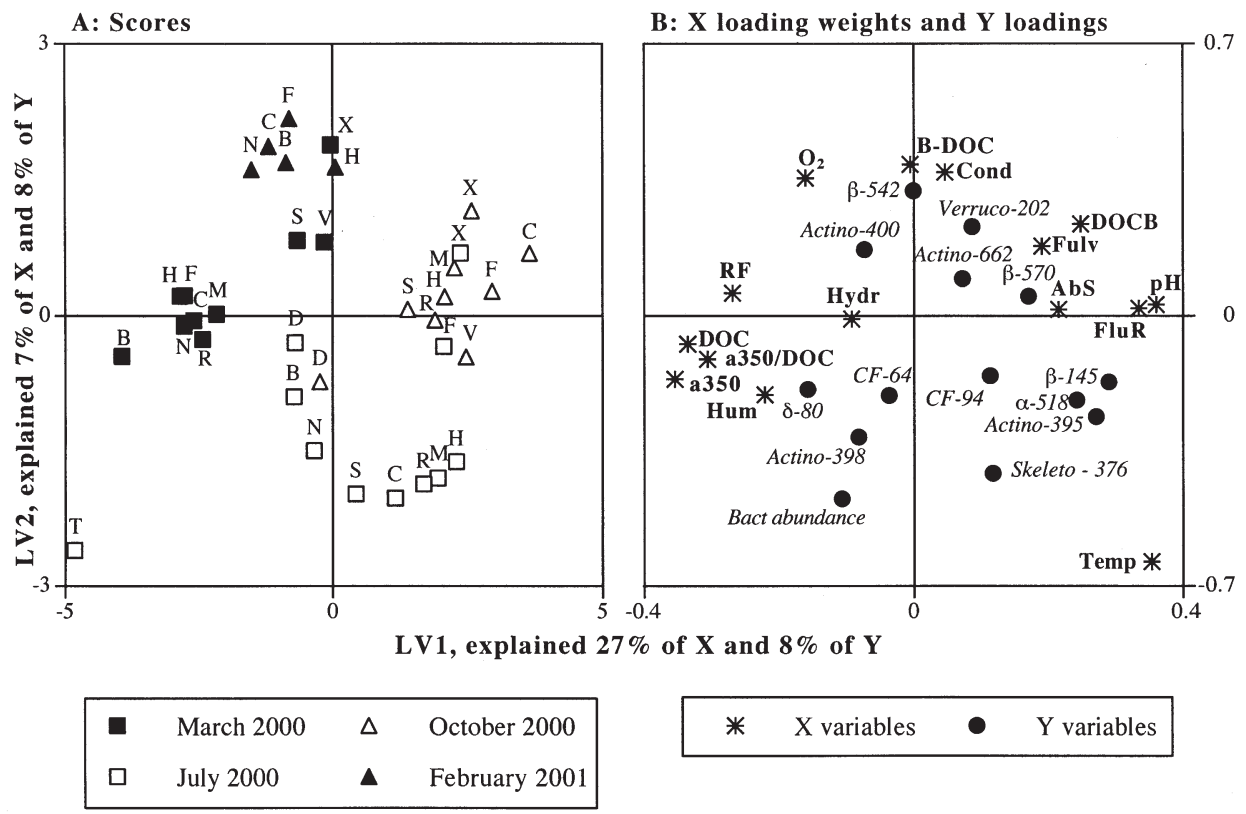

Fig. 6. First 2 latent variables (LV) from a partial least-square regression (PLS) model. (A) Scores of individual samples, (B) loadings for the predictor $(\mathrm{X})$ variables and the response $(\mathrm{Y})$ variables. Predictor variables are: the combined flow of Sacramento and San Joaquin Rivers (RF); water temperature (Temp); electric conductivity (Cond); $\mathrm{pH}_{i}$ dissolved oxygen $\left(\mathrm{O}_{2}\right)$; DOC concentration; absorbance coefficient at $350 \mathrm{~nm}$ (a350), DOC-specific a350 (a350/DOC); negative slope of log-transformed absorbance in the range 280 to $400 \mathrm{~nm}(\mathrm{AbS})$; ratio of fluorescence at 450 and $500 \mathrm{~nm}$ with excitation at $365 \mathrm{~nm}$ (FluR); humic (Hum), fulvic (Fulv) and hydrophilic (Hydr) fractions of DOC; concentration of bioavailable DOC (B-DOC); and the fraction of bioavailable DOC (DOCB). Response variables are bacterial abundance and the normalized intensities of T-RFLP peaks, tentatively identified by matching clones (Table 2). For sample abbreviations, see Table 1

on FISH, Actinobacteria made up 34,8 and $21 \%$ of DAPI counts in such contrasting environments as the oligotrophic Lake Gossenköllesse (Austria), Lake Baikal (Russia) and the acidic forest Lake Fuchskuhle (Germany), respectively, and were equally abundant

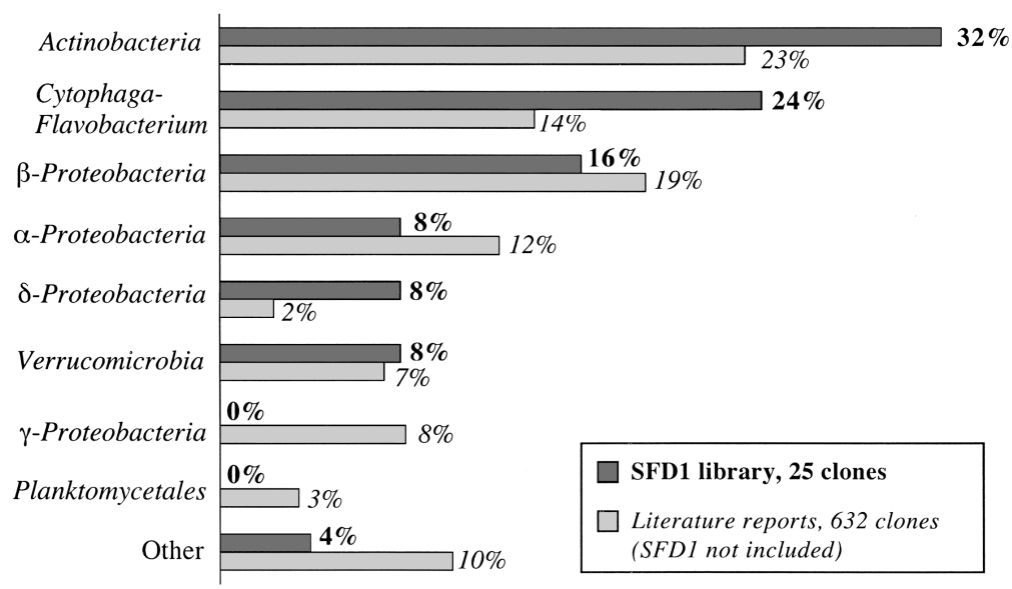

Fig. 7. Frequencies of major bacterial phylogenetic groups in the SFD1 clone library and among freshwater bacterioplankton clones reported in the literature. Sources: Bahr et al. (1996), Hiorns et al. (1997), Semenova \& Kuznedelov (1998), Zwart et al. (1998), Crump et al. (1999), Bosshard et al. (2000a), Glöckner et al. (2000), Urbach et al. (2001) as $\beta$-Proteobacteria (Glöckner et al. 2000; Fig. 8). Likewise, dot-blot DNA hybridization demonstrated that Actinobacteria contributed 18 to $48 \%$ of bacterial $16 \mathrm{~S}$ rRNA genes in the Crater Lake (Urbach et al. 2001). Since allochthonous inputs to this lake are negligible, these data most likely reflected the composition of the indigenous microbial assemblage.

The recently discovered division of Verrucomicrobia comprised $24 \%$ (median) of T-RFLP chromatograms (Figs. $3 \& 4$ ) and 7 to $8 \%$ of both SFD1 clone library and freshwater bacterioplankton sequences reported in literature (Table 2, Fig. 7). Using dot-blot DNA hybridization, Urbach et al. (2001) found that Verrucomicrobia made up 15 to $55 \%$ of bacterioplankton in the Crater Lake. To our knowledge, no FISH studies have been performed on Verrucomicrobia. Neither Actinobacteria nor Verrucomicrobia are common in the ocean (Giovanoni \& Rappé 2000). Thus, the abundance of these 2 phylogenetic divisions, as well as $\beta$-Proteobacteria, may be general features distinguishing freshwater bacterioplankton from its marine counterpart.

Several SFD1 sequences were $>99 \%$ similar to clones retrieved from geographically distant 
locations, indicating a cosmopolitan distribution. Especially interesting is the LD12 cluster of $\alpha$-Proteobacteria, which includes SFD1-3 and SFD1-12. The LD12 cluster contains the only reported cases of $100 \%$ identity of large portions of the $16 \mathrm{~S}$ rRNA gene between clones from fresh waters in different continents including Europe, North America and Asia. Since Proteobacteria are not known to form dispersal/survival stages, mechanisms of their cosmopolitan distribution are intriguing. No representatives of the LD12 cluster have been cultured so far.

SFD1 Clones 2, 19, 27 and 37 (respective terminal restriction fragment lengths 212, 428, 580 and $348 \mathrm{bp}$ ) were never detected in environmental T-RFLP profiles (Table 2). Most probably, the 4 clones represented amplicons too rare to be detected by the applied T-RFLP method, or they did not amplify well in the T-RFLP amplifications with a labeled primer. In addition, their occurrence in the clone library could be caused by a positive selection during cloning. Several authors report significant biases associated with cloning (e.g. Wintzingerode et al. 1997).

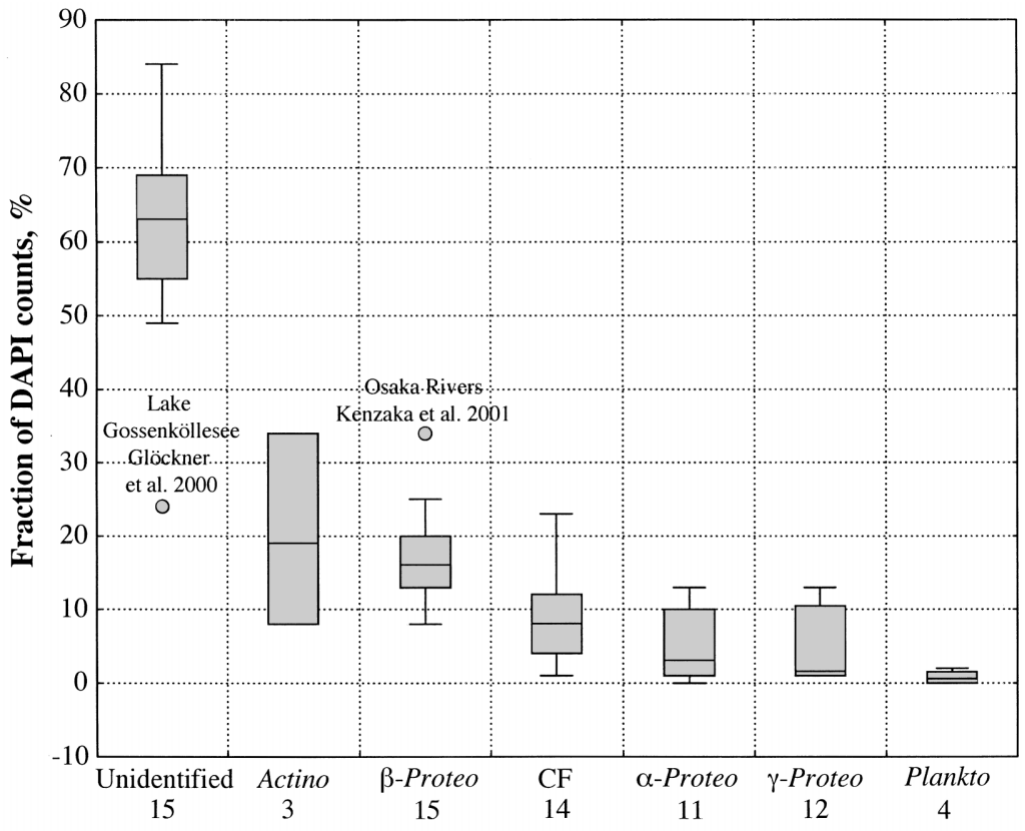

Fig. 8. Composition of freshwater bacterioplankton as determined by fluorescent in situ hybridizations with division- or subdivision-specific probes. Average values from each location and report were used for the presentation. Locations include lakes Baikal, Cadagno, Fuchskuhle and Gossenköllesee (Alfreider et al. 1996, Pernthaler et al. 1998, Glöckner et al. 1999, 2000, Bosshard et al. 2000b) and rivers Chao, Kelang, Kitahashi, Osaka (multiple rivers combined) and Takayama (Kenzaka et al. 1998, 2001). Median, 25\% percentiles, range and outliers are shown. Digits below the phylogenetic groups indicate the number of reports per group

\section{Environmental controls on bacterioplankton composition}

Despite the variety of sampled habitats (Table 1, Fig. 1) and the spatial and temporal variation in hydrology, temperature and water chemistry among the stations and sampling campaigns (Table 3, Fig. 2), T-RFLP electropherograms from all samples contained the same dominant peaks (Figs. $3 \& 4$ ). Thus, it appears that the same bacterioplankton phylotypes dominated the various habitats of the Delta throughout the year. However, differences existed in the relative intensities of T-RFLP peaks among the samples. Since PCR has been shown to give highly reproducible ratios between 16S rRNA gene amplicons when performed under identical conditions (Polz \& Cavanaugh 1998, González et al. 2000), differences in T-RFLP peak intensities likely reflect shifts in the relative abundance of microbial phylotypes. Therefore, multivariate statistical analysis of T-RFLP peak intensities has proven useful to determine ecologically meaningful differences among complex microbial assemblages in bioreactors (Dollhopf et al. 2001), biofilms (A. Buchan, S. Y. Newell, J. I.L. Moreta \& M. A. Moran unpubl.) and soils (J.E. Brofft, J.V. McArthur \& L. J. Shimkets unpubl.). However, the absolute abundance of individual phylotypes in the samples cannot be accurately determined from T-RFLP profiles due to PCR biases (Suzuki \& Giovannoni 1996, Wintzingerode et al. 1997, Polz \& Cavanaugh 1998). It also is possible that differences among the samples were not resolved by T-RFLP analysis due to fragments of the same size originating from different taxa. However, that only accounted for a small fraction of the peaks (Table 2).

The application of PCA and PLS to Delta T-RFLP profiles revealed consistent seasonal shifts of bacterioplankton composition in the Delta. T-RFLP fragments showing a relative increase during summer and fall, i.e. those with positive loadings of PC1 (Fig. 5) and LV1 (Fig. 6), were associated with low river flow, decreased DOC concentration, elevated $\mathrm{pH}$ and a number of DOC characteristics serving as indicators of an increased proportion of phytoplankton-produced material, as opposed to allochthonous, terrestrially derived DOC (Fig. 6B). Those characteristics include elevated DOC bioavailability (Søndergaard \& Middelboe 1995), elevated spectral slope coefficient $(\mathrm{AbS}$; Davies-Colley \& Vant 1987), elevated fluorescence ratio (FluR; Mc- 
Knight et al. 2001), elevated proportion of fulvic versus humic acids (McKnight \& Aiken 1998) and a decreased DOC color (a350/DOC; McKnight \& Aiken 1998). Thus, phylotypes with the highest positive loadings on LV1 $(\alpha-$ and $\beta$-Proteobacteria and Actinobacteria with TRFLP fragments of 145,395 and $518 \mathrm{bp}$ ) possibly had an ecological advantage over other taxa during summer and fall, when the Delta was enriched in bioavailable, phytoplankton-derived dissolved organic matter. In contrast, $\delta$-Proteobacteria and Actinobacteria with 80, 398 and 400 bp T-RFLP fragments had the highest negative loadings on LV1 and most likely represented cells resuspended from sediment or washed out from watershed soils during winter floods. Supporting this hypothesis, sequences of $\delta$-Proteobacteria from the SFD1 clone library were most closely related to organisms from anoxic soils (Table 2). In general, $\delta$-Proteobacteria are not a common component of planktonic assemblages either in oxygenated fresh waters (Fig. 7) or the ocean (Giovannoni \& Rappé 2000).

Published reports on the seasonal succession of freshwater bacterioplankton are scarce and typically are based on FISH analysis using division or subdivision-specific probes. These probes only account for a median of $36 \%$ of DAPI-positive bacterial cells (Fig. 8). In the alpine Lake Gossenköllesee (Austria), peaks in the relative abundance of $\alpha$-Proteobacteria, $\beta$-Proteobacteria, and Actinobacteria co-occurred during spring and late summer (Pernthaler et al. 1998, Glöckner et al. 2000). Our results show that closely related bacterioplankton phylotypes may have contrasting environmental responses (e.g. Actinobacteria with 395 398, and 400 bp T-RFLP fragments; Fig. 6). Such variation among closely related taxa would be undetected using FISH probes with broad phylogenetic resolution.

The lack of consistent spatial patterns in PCA analysis of T-RFLP patterns (Fig. 5A) suggests that minor differences in bacterioplankton composition among the stations was due to random variation as opposed to environmental factors promoting local selected growth or removal. Possibly, water residence time in the individual sampled habitats was too short for distinct local bacterioplankton assemblages to develop. Low bacterioplankton growth with estimated doubling times of 4 to $9 \mathrm{~d}$ in the Delta (Sobczak et al. 2002) and 0.6 to $3.5 \mathrm{~d}$ in the oligohaline reach have been measured in the San Francisco Bay (Hollibaugh \& Wong 1996, 1999). The median water residence time in the Delta is $25 \mathrm{~d}$ (Jassby \& Cloern 2000) and probably varies from several hours to several days in the sampled habitats. In this regard, it is interesting that Stn S, which is part of the Yolo bypass, demonstrated the broadest seasonal variation in bacterioplankton composition among the sampled stations (Fig. 5A). During winter, this station receives water circulated through a large area of flood plain and may carry substantial quantities of terrestrial microorganisms. During summer, the station is semiisolated with no flow-through, which may favor the formation of distinct local microbial assemblages.

Variables not considered here, particularly those involved in trophic interactions, may influence bacterioplankton composition. For example, several mesocosm studies demonstrated that selective grazing by protists favors large and filamentous bacteria of varying phylogenetic affiliations (e.g. Simek et al. 2001, Matz et al. 2002). Also, field studies of mixotrophic protists (Lindström 2001) and zooplankton (Höfle et al. 1999) have indicated that grazing can be the main factor responsible for changes in freshwater bacterioplankton composition. It is known that the invasive Asian clams Potamocorbula amurensis in the San Francisco Bay exhibit high grazing pressure on picoplankton, possibly including bacteria (Werner \& Hollibaugh 1993, Murrell \& Hollibaugh 1998), although the consequential effects on microbial assemblage structure are unknown. Inorganic nutrient limitation might influence community composition, although the Delta typically is replete in nitrogen and phosphorus year-round (Jassby \& Cloern 2000). Viruses also may play an important role in shaping the composition of bacterial assemblage via species-specific cell lysis, although field studies supporting this hypothesis are scarce (Wommack \& Colwell 2000).

\section{CONCLUSIONS}

Consistent seasonal but not spatial variation in bacterioplankton composition was found in PCA and PLS analyses of the 16S rRNA gene T-RFLP peak intensities in the Sacramento-San Joaquin River Delta, CA. Several phylotypes of Actinobacteria, $\alpha$-Proteobacteria and $\beta$ Proteobacteria appeared to be favored by summer conditions indicative of an increased proportion of bioavailable, phytoplankton-derived dissolved organic matter. On the other hand, winter increases in $\delta$-Proteobacteria probably were due to cell resuspension from sediments and soils. Various phylotypes from the same phylogenetic division exhibited diverse temporal patterns, suggesting that ecological roles of Delta bacterioplankton were partitioned at the genus or species level.

Acknowledgements. We thank Alison Buchan, Nasreen Bano and Joe Covert for useful advice on construction of clone libraries and T-RFLP analysis, Rich Losee and the Delta group at the US Geological Survey (USGS) in Sacramento for great cooperation during the fieldwork, and Stefan Bertilsson for providing access to a flow cytometer and for advice on multivariate statistics. This work was supported by CalFed Category III funds via Cooperative Agreement number 00WRAG0004 administered by the USGS. 


\section{LITERATURE CITED}

Alfreider A, Pernthaler J, Amann R, Sattler B, Glöckner FO, Wille A, Psenner R (1996) Community analysis of the bacterial assemblages in the winter cover and pelagic layers of a high mountain lake by in situ hybridization. Appl Environ Microbiol 62:2138-2144

Altschul SF, Madden TL, Schäffer AA, Zhang J, Zhang Z, Miller W, Lipman DJ (1997) Gapped BLAST and PSIBLAST: a new generation of protein database search programs. Nucleic Acids Res 25:3389-3402

Avaniss-Aghajani K, Jones K, Holzman A, Aronson T, Glover N, Boian M, Froman S, Brunk CF (1996) Molecular technique for rapid identification of Mycobacteria. J Clin Microbiol 34:98-102

Bahr M, Hobbie JE, Sogin ML (1996) Bacterial diversity in an arctic lake: a freshwater SAR11 cluster. Aquat Microb Ecol 11:271-277

Bosshard PP, Santini Y, Grüter D, Steller R, Bachofen R (2000a) Bacterial diversity and community composition in the chemochline of a meromictic alpine Lake Cadagno as revealed by $16 \mathrm{~S}$ rDNA analysis. FEMS Microb Ecol 31: 173-182

Bosshard PP, Steller R, Bachofen R (2000b) Seasonal and spatial community dynamics in the meromictic Lake Cadagno. Arch Microbiol 174:168-174

Bouvier TC, del Giorgio PA (2002) Compositional changes in free-living bacterial communities along a salinity gradient in 2 temperate estuaries. Limnol Oceanogr 47:453-470

Covert JS, Moran MA (2001) Molecular characterization of estuarine bacterial communities that use high- and lowmolecular weight fractions of dissolved organic carbon. Aquat Microb Ecol 25:127-139

Crump BC, Virginia Armbrust E, Baross JA (1999) Phylogenetic analysis of particle-attached and free-living bacterial communities in the Columbia River, its estuary, and the adjacent coastal ocean. Appl Environ Microbiol 65: 3192-3204

Davies-Colley RJ, Vant WN (1987) Absorption of light by yellow substance in freshwater lakes Limnol Oceanogr 32: 416-425

del Giorgio PA, Bird DF, Prairie YT Planas D (1996) The flow cytometric determination of bacterial abundance in lake plankton with the green nucleic acid stain SYTO 13. Limnol Oceanogr 41:783-789

Dollhopf SL, Hashsham SA, Tiedje JM (2001) Interpreting 16S rDNA T-RFLP data: Application of self-organizing maps and principal component analysis to describe community dynamics and convergence. Microb Ecol 42:495-505

Felsenstein J (1989) PHYIP - Phylogeny inference package (version 3.2). Cladistics 5:164-166

Fuchs BM, Zubkov MV, Sahm K, Burkill PH, Amann R (2000) Changes in community composition during dilution cultures of marine bacterioplankton as assessed by flow cytometric and molecular biological techniques. Environ Microbiol 2:191-201

Giovannoni S, Rappé M (2000) Evolution, diversity, and molecular ecology of marine procaryotes. In: Kirchman DL (ed) Microbial ecology of the oceans. Wiley-Liss, New York, p 47-84

Glöckner FO, Fuchs BM, Amann R (1999) Bacterioplankton compositions of lakes and oceans: a first comparison based on fluorescent in situ hybridization. Appl Environ Microbiol 65:3721-3726

Glöckner FO, Zaichikov E, Belkova N, Denissova L, Pernthaler J, Pernthaler A, Amann R (2000) Comparative 16S rRNA analysis of lake bacterioplankton reveals globally distributed phylogenetic clusters including an abundant group of Actinobacteria. Appl Environ Microbiol 66: 5053-5065

González JM, Moran MA (1997) Numerical dominance of a group of marine bacteria in the $\alpha$-subclass of the class Proteobacteria in coastal seawater. Appl Environ Microbiol 63:4237-4242

González JM, Simo R, Massana R, Covert JS, Casamayor EO, Pedrós-Alio C, Moran MA (2000) Bacterial community structure associated with a dimethylsulfoniopropionateproducing North Atlantic algal bloom. Appl Environ Microbiol 66:4237-4246

Good IJ (1953) The population frequencies of species and the estimation of population parameters. Biometrika 40: 237-264

Hiorns WD, Methé BA, Nierzwicki-Bauer SA, Zehr JP (1997) Bacterial diversity in Adirondack mountain lakes as revealed by $16 \mathrm{~S}$ rRNA gene sequences. Appl Environ Microbiol 63:2957-2960

Höfle MG, Haas H, Dominik K (1999) Seasonal dynamics of bacterioplankton community structure in a eutrophic lake as determined by 5S rRNA analysis. Appl Environ Microbiol 65:3164-3174

Hollibaugh JT, Wong PS (1996) Distribution and activity of bacterioplankton in San Francisco Bay. In: Hollibaugh JT (ed) San Francisco Bay, the ecosystem. American Association for the Advancement in Science, San Francisco, p 263-288

Hollibaugh JT, Wong PS (1999) Microbial processes in the San Francisco Bay estuarine turbidity maximum. Estuaries 22:848-862

Jassby AD, Cloern JE (2000) Organic matter sources and rehabilitation of the Sacramento-San Joaquin delta (California, USA). Aquat Conserv Mar Freshw Ecosyst 10:323-352

Kenzaka T, Yamaguchi N, Tani K, Nasu M (1998) rRNAtargeted fluorescent in situ hybridization analysis of bacterial community structure in river water. Microbiology 144:2085-2093

Kenzaka T, Yamaguchi N, Prapagdee B, Mikami E, Nasu M (2001) Bacterial community composition and activity in urban rivers in Thailand and Malaysia. J Health Sci 47: 353-361

Lindström ES (2001) Investigating influential factors on bacterioplankton community composition: Results from a field study of 5 mesotrophic lakes. Microb Ecol 42:598-605

Maidak BL, Larsen N, McCaughey MJ, Overbeek R, Olsen GJ, Fogel K, Blandy J, Woese CR (1994) The ribosomal database project. Nucleic Acid Res 22:3485-3487

Malcolm RL, MacCarthy P (1992) Quantitative evaluation of $\mathrm{XAD}-8$ and XAD- 4 resins used in tandem for removing organic solutes from water. Environ Int 18:597-607

Matz C, Boenigk J, Arndt H, Jürgens K (2002) Role of bacterial phenotypic traits in selective feeding of the heterotrophic nanoflagellate Spumella sp. Aquat Microb Ecol 27: 137-148

McKnight DM, Aiken GR (1998) Sources and age of aquatic humus. In: Hessen DO, Tranvik LJ (eds) Aquatic humic substances. Springer-Verlag, Berlin, p 9-39

McKnight DM, Boyer EW, Westerhoff PK, Doran PT, Kulbe T, Andersen DT (2001) Spectrofluorometric characterization of dissolved organic matter for indication of precursor organic material and aromaticity. Limnol Oceanogr 46: $38-48$

Methé BA, Zehr JP (1999) Diversity of bacterial communities in Adirondack lakes: Do species assemblages reflect lake water chemistry? Hydrobiologia 401:77-96 
Moran MA, Rutherford LT, Hodson RE (1995) Evidence for indigenous Streptomyces populations in a marine environment determined with a 16S rRNA probe. Appl Environ Microbiol 61:3695-3700

Murrell MC, Hollibaugh JT (1998) Microzooplankton grazing in northern San Francisco Bay measured by the dilution method. Aquat Microb Ecol 15:53-63

Pernthaler J, Glöckner FO, Unterholzner S, Alfreider A, Psenner R, Amann R (1998) Seasonal community and population dynamics of pelagic Bacteria and Archea in a high mountain lake. Appl Environ Microbiol 64:4299-4306

Polz MF, Cavanaugh CM (1998) Bias in template-to-product ratios in multitemplate PCR. Appl Environ Microbiol 64: 3724-3730

Semenova EA, Kuznedelov KD (1998) A study of the biodiversity of Baikal picoplankton by comparative analysis of $16 \mathrm{~S}$ rRNA gene 5'-terminal regions. Mol Biol 32:895-901

Simek K, Pernthaler J, Weinbauer MG, Hornák K, Dolan JR, Nedoma J, Masin M, Amann R (2001) Changes in bacterial community composition and dynamics and viral mortality rates associated with enhanced flagellate grazing in a mesoeutrophic reservoir. Appl Environ Microbiol 67: $2723-2733$

Sobczak WV, Cloern JE, Jassby AD, Mueller-Solger AB (2002) Bioavailability of organic matter in a highly disturbed estuary: the role of detrital and algal resources. Proc Natl Acad Sci USA 99:8101-8105

Søndergaard M, Middelboe M (1995) A cross-system analysis

Editorial responsibility: Jed Furhman,

Los Angeles, California, USA of labile dissolved organic carbon. Mar Ecol Prog Ser 118: 283-294

Suzuki MT, Giovannoni SJ (1996) Bias caused by template annealing in the amplification of mixtures of 16S rRNA genes by PCR. Appl Environ Microbiol 62:625-630

Thompson JD, Gibson TJ, Plewniak F, Jeanmougin F, Higgins DG (1997) The ClustalX windows interface: Flexible strategies for multiple sequence alignment aided by quality analysis tools. Nucleic Acids Res 24:4876-4882

Urbach E, Vergin KL, Young L, Morse A (2001) Unusual bacterioplankton community structure in ultra-oligotrophic Crater Lake. Limnol Oceanogr 46:557-572

Werner I, Hollibaugh JT (1993) Potamocorbula amurensis: Comparison of clearance rates and assimilation efficiencies for phytoplankton and bacterioplankton. Limnol Oceanogr 38:949-964

Wintzingerode F, Göbel UB, Stackebrandt E (1997) Determination of microbial diversity in environmental samples: pitfalls of PCR-based rRNR analysis. FEMS Microb Rev 21: 213-229

Wommack KE, Colwell RR (2000) Virioplankton: viruses in aquatic ecosystems. Microbiol Mol Biol Rev 64:69-114

Zwart G, Hiorns WD, Methé BA, van Agterveld MP, Huismans R, Nold SC, Zehr JP, Laanbroek HJ (1998) Nearly identical 16S rRNA sequences recovered from lakes in North America and Europe indicate the existence of clades of globally distributed freshwater bacteria. Syst Appl Microbiol 21:546-556

Submitted: May 16, 2002; Accepted: August 30, 2002 Proofs received from author(s): February 4, 2003 